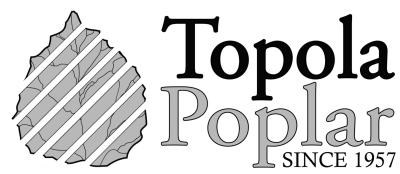

Preliminary report

\title{
Recent Records of the Cypress Jewel Beetle - Lamprodila (Palmar) festiva (Linnaeus, 1767) (Coleoptera: Buprestidae) in Serbia
}

\author{
Tatjana Kereši \\ University of Novi Sad, Faculty of Agriculture, Novi Sad, Serbia \\ E-mail: tkeresi50@gmail.com
}

Received: 16 Mar 2020; Revised: 8 Apr 2020; Accepted: 25 Apr 2020

\begin{abstract}
Lamprodila (Palmar) festiva (Linnaeus, 1767), cypress jewel beetle is a species widespread in the Mediterranean, but has been rapidly expanding north and east over the last decade. It is harmful to plants of the genus Juniperus, Chamaecyparis, Cupressus, Platycladus and Thuja. It attacks both, the healthy and stressed plants and destroys them within 2-3 years. There is lack of information about this buprestid in Serbia, except that heavy damage from it was registered in 2014, without specifying localities of the damage. This work provides exact geographical records where species was noticed in Serbia (near Belgrade and Sremski Karlovci) during past two years. Considering the great damage it can cause, much more attention should be paid in the future to monitoring the occurrence and abundance of this species, particularly in the nurseries and new planted hedges.
\end{abstract}

Keywords: Lamprodila (Palmar) festiva, distribution, description, biology, harmfulness and suppression.

\section{Introduction}

Lamprodila (Palmar) festiva (Linnaeus, 1767) beetle is commonly known as cypress jewel beetle. It usually develops on Juniperus spp., but recently adapted to new host plants like Chamaecyparis spp., Cupressus spp., Platycladus spp. and Thuja spp., all belonging to the cypress family (Cupressaceae). It attacks both, the healthy and stressed plants (due to summer heat and drought) and destroys them within 2-3 years.

Adults of L. (P.) festiva have an elongated oval body, 6-12 $\mathrm{mm}$ long and about 4-6 $\mathrm{mm}$ wide. The general color is metallic blue-green, with two dark spots on the pronotum and several symmetrical black-blue spots on the elytra. The ventral side of body is green with bluish and golden glow, while the dorsal side of abdomen and wings are dark purple. Larvae are white, legless, 15-20 mm long, with a distinct first thoracic segment wider than abdominal segments. Pupae are white, naked, soft, similar size as imago (Razinger et al. 2013).

Due to climate changes and global trading which triggered massive environmental changes many invasive and adventive species start to occupy new areas. During the last decade and most probably even earlier L. (P.) festiva is spreading rapidly from its native Mediterranean areal to the North and East. According to Jendek et al. (2018), this species is present in Europe: Albania, Austria, Bosnia and Herzegovina, Bulgaria, Croatia, Czech Republic, France, Germany, 
Greece, Hungary, Italy, Luxembourg, Montenegro, North Macedonia, Portugal, Romania, Russia (Krasnodar), Slovakia, Slovenia, Spain, Switzerland; northern Africa: Algeria, Morocco and Tunisia; western Asia: Turkey, Lebanon and Syria. Worth mentioning is that species includes three subspecies, of which the nominotypic [L. (P.) festiva festiva (Linnaeus, 1767)] inhabits Europe and northern Africa, the second one [L. (P.) festiva holzschuhi (Hellrigl, 1972)] lives in western Asia, while the third, L. (P.) festiva cretica (Zabransky, 1994) is endemic for Crete island.

Damage caused by L. (P.) festiva during 2012 was observed in Budapest, mostly on Platycladus orientalis (L.) Franco. Until that finding named buprestid was protected species and considered rare in Hungary. Recorded mass occurrence of the species is an evident proof the rapid spread of this new pest in horticulture (Németh, 2013). Based on this information, Kereši (2013) briefly informed the professional public about the possible presence of this species in the near future on the territory of neighboring Serbia.

Glavendekić et al. (2014) published that in the spring of 2014, the appearance of cypress jewel beetle was recorded in nurseries, parks, private gardens and hedges in urban areas at many localities in Republika Srpska and Serbia (without specifying localities). Species caused great economic loss and thousands of plants (mostly Thuja occidentalis L. cultivars) were destroyed. Therefore authors suggested that this species should be put on the list of economically important pests and included in the list of pests for regular inspection in nurseries.

This paper defines two localities where the pest was found in Serbia during last two years (including 12th March 2020), as well as literature data on its distribution in Europe, the mode of damage and possible measures of suppression.

\section{Results and discussion}

There were no published data on the presence or damage of L. (P.) festiva in our country, except the mentioned reference of Glavendekić et al. (2014). On the website BioRas this species is on the list of Buprestidae of Serbia under synonym Ovalisia festiva (Simonović, 2014), but there are no data on its findings in the country, nor any photographs posted.

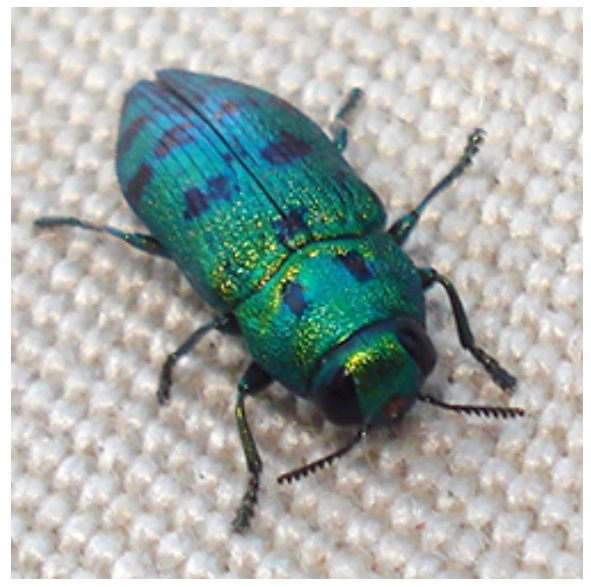

Figure 1. Lamprodila festiva (photo: D. Ćoso)

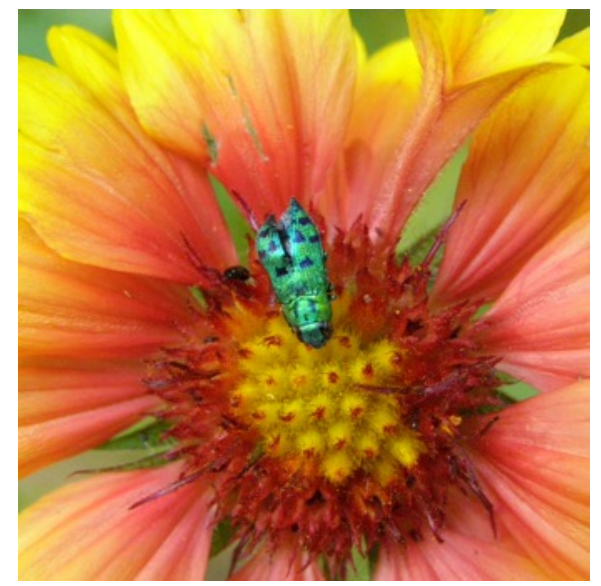

Figure 2. L. festiva on Gaillardia flower (photo: T. Kereši)

In the Alciphron database, made by Facebook group Insects of Serbia, till 2019, one record (Anonymous, 2018) was posted on a map, under name O. festiva, including a photograph of the 
beetle taken by Denis Ćoso. In private correspodence, Mr. Denis Ćoso kindly replied that he found one live adult of O. festiva (Figure 1) in June 2018, on the wall of his house in the village

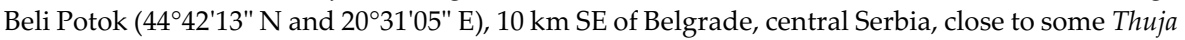
trees. Identification of that specimen was confirmed by Nikola Rahme, a known specialist for the family Buprestidae (Rahme, 2013).

On May $31^{\text {th }} 2019$, on the outskirts of Sremski Karlovci $\left(45^{\circ} 12^{\prime} 09^{\prime \prime} \mathrm{N}\right.$ and $\left.19^{\circ} 56^{\prime} 02^{\prime \prime} \mathrm{E}\right)$, in northern Serbia, one live, slightly damaged adult of L.(P.) festiva, which glowed on a flower of Gaillardia x grandiflora (Asteraceae), accidentally was noticed by author (Figure 2). The flower was close to a tree of the Chamaecyparis lawsoniana (A. Murray) that began to dry in 2012, and which top and branches were removed in 2016, but the tree still stands. After a closer look at the southern and southwestern side of the trunk plenty of oval exit holes, about $4 \mathrm{~mm}$ long and 2 mm wide (Figure 3) were seen, apparently drilled by the mentioned pest. On $12^{\text {th }}$ June 2019 , at the same tree, another adult was seen protruding from its exit hole, but it was dead, without antennas, which were likely eaten by birds which are quite numerous in surroundings. Both insects were about $8 \mathrm{~mm}$ long, which indicated that they are males, but sex was not identified. On 12 $2^{\text {th }}$ March 2020, seven more dead half decayed specimens of this pest (six was $8 \mathrm{~mm}$ long and one was $10 \mathrm{~mm}$ ) were found on the same trunk under the peeled bark. Apparently this trunk served as trapping tree for dozens of specimens found only on it. At 1-2 $\mathrm{m}$ distance there are two trees of Thuja orientalis, planted at the same time when the trapping tree, but those two trees didn't show any sign of insect's presence or damage. Figure 4 shows the galleries drilled by larvae and sawdust, while the current known distribution of the beetle in Serbia is presented in Figure 5. Photos, along with the time of the beetle's observation and exact localities where the beetles were found are stored in the Alciphron database.
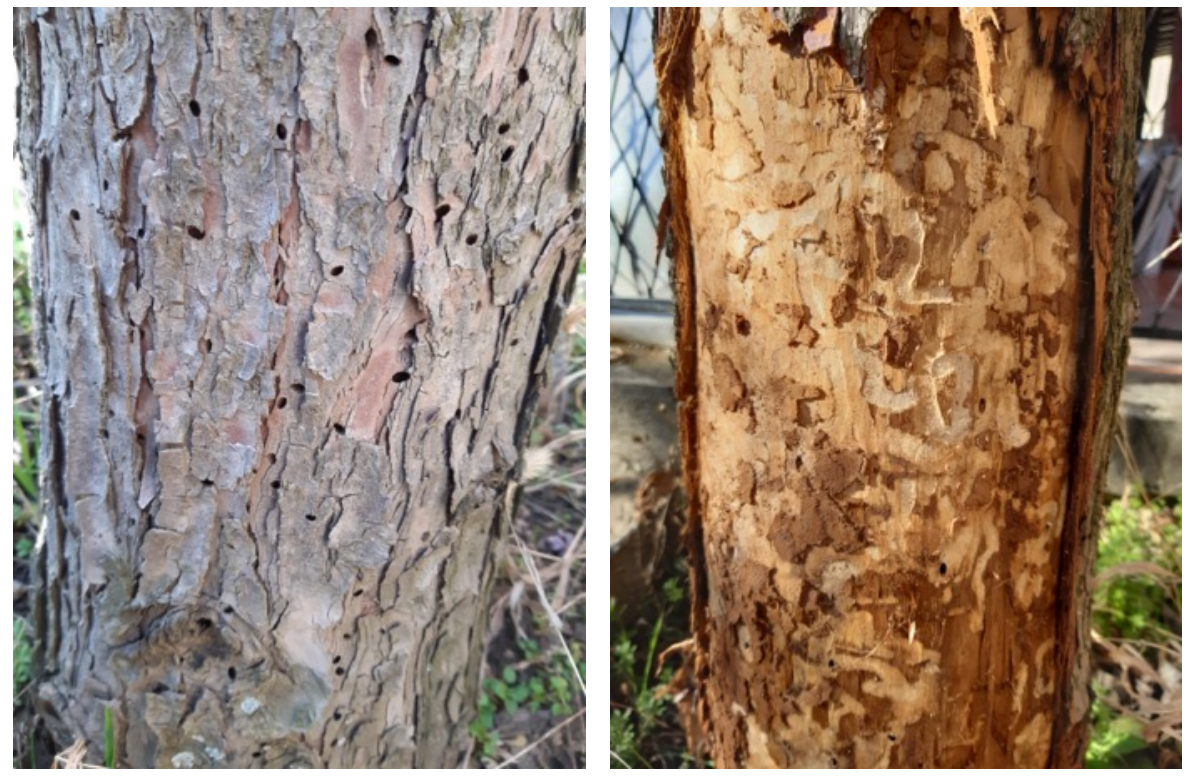

Figure 3-4. Exit holes (left) and galleries (right) of L. (P) festiva on Chamaecyparis trunk (photo: T. Kereši)

During the study of the Buprestidae fauna in the Fruška Gora National Park (at the edge of which is the place Sr. Karlovci), that lasted eight years in the period 2003-2014, Stojanović et 
al. (2015) did not find O. (P.) festiva within a total number of 14 species. This is not surprising, as coniferous forests make up only about $2 \%$ of the forests of Fruska Gora.

Over the past 10 years, the occurrence and damage caused by L. (P.) festiva have been reported from several neighboring countries as well as from other countries of southern and central Europe. For example, this pest has been previously present in Italy, as a Mediterranean country, but in recent years the strong spread was recorded to the North as a result of the increase demands for ornamental plants in gardens (especially for hedges and borders), and therefore, species increased its abundance in nurseries too. Consequently, this beetle has become an economically significant pest, causing heavy damage to host species (Salvetti, 2013; Pedersoli, 2016).

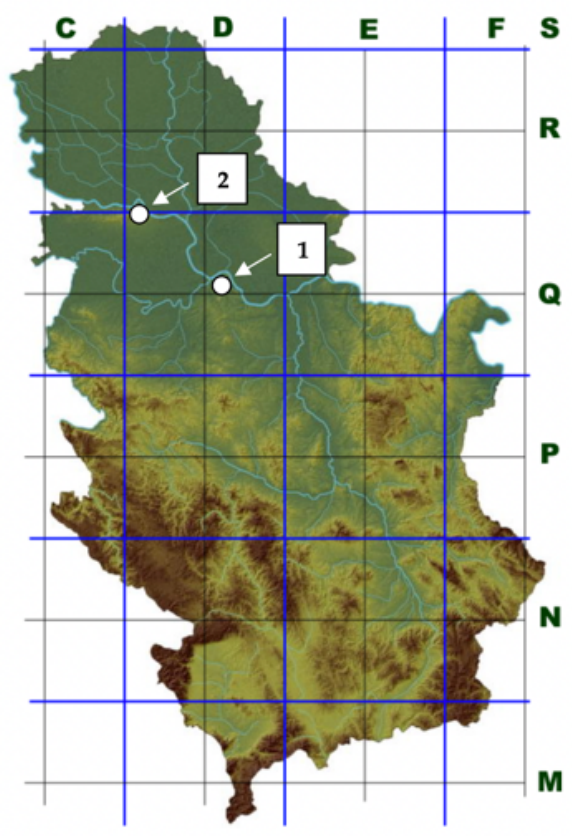

Figure 5. Distribution of Lamprodila festiva in Serbia: 1 - Belgrade (UTM DQ56), 2 - Sremski Karlovci (UTM DR10).

A significant drying and dying of white cedars (Thuja occidentalis) in an older hedge were observed in autumn 2010 in Ljubljana (Slovenia). In April and May 2012 similar damage was recorded in several gardens in Ljubljana (Trnovo, Bežigrad), Posavje (Žadovinek) and Prekmurje (Lendava). Razinger et al. (2013) conclude that the native population of L. festiva that normally feeds on junipers found a niche in the white cedars growing in permanent sites or in nurseries.

Glavendekić et al. (2014) reported significant damage in the form of partial and complete decay of conifers (Thuja and Chamaecyparis) in nurseries and private gardens during 2010-2011 in Montenegro (Danilovgrad) and Republika Srpska (Banja Luka and Prijedor). In order to determine the cause of this occurrence, during 2010-2014, samples were collected from nurseries and green spaces in the mentioned countries, as well as in Serbia (without specifying localities). Samples of infested branches, tree and root collar were brought to the entomological laboratory of the Faculty of Forestry in Belgrade and reared to adult stage in order to identify them. In all samples there were identified adults of the L. (P.) festiva. 
In the Romanian fauna, the only records of this species for a long time were four specimens found in the middle of $20^{\text {th }}$ century. But, in 2014, the species was found to occur in large number and cause serious damage to T. occidentalis (cultivar "Emerald") in the southern Romania (Nitzu et al., 2016). During 2017-2018, the species was also found in the Cluj area (central part of the country) where it was very harmful to T. occidentalis in urban areas (Bunescu and Florian, 2019).

According to Rabl et al. (2017), cypress jewel beetle used to be rarely species, found sporadically in certain localities of Austria and was not considered as significant one. But, during 2016, it was recorded in several localities in eastern Austria (lower Austria and Vienna), only on Thuja species. The same authors point out, based on a several literature sources, that the species is increasingly recorded also in Switzerland and Germany, and that the so far northernmost finding is in the Netherlands.

In Slovakia, the only information on this species are three museum specimens dating back to 1930s. The first recent record dates from 2017, when four specimens of L. (P.) festiva were collected by Malaise trap in Bratislava-Rača. By July 2018, the species was registered in southwestern Slovakia (Bratislava, Nitra, Kamenica nad Hronom) on plants from the genera Thuja spp. and Juniperus spp. Based on the massive occurrence in Bratislava during May-July 2018, the species is well established in Slovakia and its actual areal in the country is likely much more extensive (Jendek et al. 2018).

After the first record in Sochi in 2013, L. (P.) festiva has become common in the southern part of European Russia near the Black Sea Coast where it caused severe damage to plants from the genera Thuja, Chamaecyparis, Juniperus and Cupressus (Volkovitsh and Karpun, 2017).

In Croatia this species is consider as economically important pest of T. occidentalis, particularly "Smaragd" and "Columna" cultivars (Šubić, 2018) and in Montenegro as well (Kandić, 2019).

Ruseva et al. (2020) report that there are data on this species in Bulgaria since about 90 years, but until the last few years it was very rare and did not pose threat to plants. At the beginning of the $21^{\text {st }}$ century, this pest was found mainly in the southwestern part of country, while the most recent surveys during 2016-2019 showed that it is widely distributed in Bulgaria and can be considered as an important pest in the landscape practice.

\subsection{Biology and harmfulness}

In the Mediterranean area, this species might finish the whole life cycle for one year, while in the northern regions developing can be prolonged to two and even three years (Hellrigl, 1972; Wermelinger, 2011, cit. Razinger et al. 2013). Overwinter in the larval stage in the galleries below the bark. Grown larvae pupate in chambers quite shallowly beneath the bark and these spots are outside recognized by white sawdust. During May and June, adults chew their way out using strong maxillae and emerge through characteristic oval holes (Jendek et al. 2018).

The adults of L. (P.) festiva are heliophile and thermophilic, active during the day. They fly into the treetop, to the outer edge of the branches. The period of the mating flight is lasts during May to August. Females lay eggs on trunks or branches, predominantly on sun exposed sites. Larvae develop in the lower parts of branches or trunks where they dig sinuous sub-cortical galleries that affect the phloem tissue, deteriorate the xylem and decrease the mechanical integrity of the trunk and branches. The first signs of the attack are chlorosis followed by withering of the leaves (Razinger et al. 2013). Individual branches, and later entire plants, turn reddish-brown and finally dry out.

\subsection{Control measures}

One of the first possible control measure to slow down the insect's spread should be the right selection of ornamental plants, which are well adapted to environmental conditions. 
During investigations in June 2013 and January 2014 at the Central Conifer Collection of Corvinus University Budapest, Schmidt et al. (2014) found differences of resistance or tolerance against environmental conditions and cypress beetle injuring between 108 cultivars of genus Thuja and Platycladus. In all the taxa some cultivars that show less vulnerability were found.

Croatian author Šubić (2018) points out that it is necessary to regularly control conifer plantings, which needs to be plowed, irrigated, fertilized and preventively protected. The same author recommends "bathing" complete plants with water once a week, as this can remove many insects that attack the hedgerows. If pest specimens or damage is observed, the affected branches should be cut off and burned, and the infested plants treated by registered insecticides.

Kandić (2019) recommends that in regions with a large number of nurseries it is necessary to burn all plants attacked by L. (P.) festiva. The rest of plants should be protected by winter treatment with mineral oils. Later, during flight period of pest, combinations of preparations from groups of pyrethroids and neonicotinoids should be used, taking care to avoid the bee flight period. Setting up red sticky traps can also give some results, as they can help in pest abundance reduction.

\section{Conclusions}

Like in all mentioned countries, the climate conditions in Serbia are suitable for reproduction and development of $L$. (P.) festiva, especially during hot and dry summers. It should be expect that this pest could greatly expand in the years to come and cause significant economic damage to Thuja spp. and other conifers. Therefore, more emphasis should be put on proper selection of the hedge-plants, regular and professional monitoring of the pest and conduction of available protection measures on time.

\section{Acknowledgement}

Thanks to Mr. Denis Ćoso for permission to be included in this study his photography and data from the Alciphron database. Also, thanks to Dr. Srećko Ćurčić for helpful suggestions during the preparation of the manuscript.

\section{References}

1. Anonymous (2018): Alciphron - baza podataka o insektima Srbije (Coleoptera), HabiProt. Retrieved from:

http://alciphron.habiprot.org.rs/pregled.php?grupa=1\&vrsta=101745

2. Bunescu, H., Florian, T. (2019): The jewel beetle Lamprodila (Palmar) festiva Linné, 1767, a new invasive urban pest of Cupressaceae in Cluj area (Romania) (Coleoptera: Buprestidae). Fragmenta entomologica 51(2): 241-246.

3. Glavendekić, M., Mihajlović, Lj., Stanivuković, Z. (2014): Palmar festiva (Coleoptera: Buprestidae) a pest of Thuja and Chamaecyparis cultivars. Book of abstracts from VII Congress on plant protection, November 24-28, Zlatibor, Serbia: 276-277.

4. Jendek, E., Poláková, J., Szopa, R., Kodada, J. (2018): Lamprodila (Palmar) festiva (Coleoptera, Buprestidae) a new adventive jewel beetle pest of Cupressaceae in Slovakia. Entomofauna carpathica 30(1): 13-24.

5. Kandić, B. (2019): Tuja traži stalnu pažnju i nadzor, ali i zimski tretman. Agroklub, Podgorica. Retrieved from: https://www.agroklub.rs/ukrasno-lekovito-bilje/tuja-trazistalnu-paznju-i-nadzor-ali-i-zimski-tretman/48010/

6. Kereši, T. (2013). Čempresov krasac (Lamprodila festiva), zaštićena vrsta postaje nova štetočina zimzelenog drveća u Mađarskoj. Biljni lekar 41(4): 476. 
7. Németh, T. (2013). A boróka-tarkadíszbogár (Lamprodila festiva) megjelenése és kártétele Budapesten. Növényvédelem 49(8): 367-369.

8. Nitzu, E., Dobrin, I., Dumbravă, M., Gutue, M. (2016): The Range Expansion of Ovalisia festiva (Linnaeus, 1767) (Coleoptera: Buprestidae) in Eastern Europe and Its Damaging Potential for Cupressaceae. Travaux du Muséum National d'Histoire Naturelle "Grigore Antipa" 58(1-2): 51-57.

9. Pedersoli, D. (2016): Presenza di Lamprodila (Palmar) festiva Linneo 1767 in due siti nelle province di Brescia e Bergamo (Coleoptera Buprestidae Buprestinae). "Natura Brescia" Ann. Mus. Civ. Sc. Nat. Brescia 40: 143-144.

10. Rabl, D., Rabl, C., Rabl, S. (2017): The Mediterranean distributed Cypress Jewel Beetle Ovalisia festiva (Linneus, 1767) has riched the east of Austria (Coleoptera: Buprestidae). Entomologische Zeitschrift Schwanfeld 127(2): 109-111.

11. Rahme, N. (2013) Beautiful white cedar pest. Available online at: www.macroadventures.com $\backslash 2013 \backslash 06$

12. Razinger, J., Žerjav, M., Modic, Š. (2013): Thuja occidentalis L. is commonly a host for Cypress Jewel Beetle (Ovalisia festiva L.) in Slovenia. Zbornik predavanj in referatov 11. Slovenskega posvetovanja o varstsu rastlin z mednarodno udeležbo, March 5-6, Bled, Slovenia: 359-365.

13. Ruseva, S., Todorov, I., Pencheva, A. (2020): Ovalisia (Palmar) festiva (Linnaeus) (Coleoptera: Buprestidae) and its natural enemies reported from Bulgaria. Ecologica Montenegrina 28: 53-60.

14. Salvetti, M. (2012): Lamprodila festiva (Coleoptera, Buprestidae), specie olomediterranea legata alle piante dei generi Thuja, Juniperus, Cupressus. Il naturalista valtellinese 23: 4749.

15. Schmidt, G., Sütöriné Diószegi, M, Szabó, V., Hrotkó, K. (2014): Cypress borer (Lamprodila festiva), a new urban pest in Hungary. In: Rovná, K., Kollár, J. (eds.). Plants in Urban Areas and Landscape, Slovak University of Agriculture, Nitra, Slovakia: 32-34.

16. Simonović, I. (2014): Buprestidae Biološka raznovrsnost Srbije.

17. Stojanović, D.V., Ćurčić, S.B., Kereši, T.B. (2015): A contribution to the knowledge of the phytophagous jewel beetles (Coleoptera: Buprestidae) of the Fruška Gora National Park. In: D. Marčić, M. Glavendekić, P. Nicot (Eds.) Proceedings of the 7th Congress on Plant Protection, Plant Protection Society of Serbia, IOBC-EPRS, IOBC-WPRS, 2015, Belgrade, pp. 211-216.

18. Šubić, M. (2018): Bolesti i štetnici ukrasnih tuja. Gospodarski list, 1. Zagreb.

19. Volkovitsh M.G., Karpun N.N. (2017): A new invasive species of buprestid beetles in the Russian fauna: Lamprodila (Palmar) festiva (L.) (Coleoptera, Buprestidae), a pest of Cupressaceae. Entomological Review 97(4): 425-437. 